\title{
Development of ROV Trencher URI-T and its Sea Trial
}

\author{
Hyungjoo Kang ${ }^{(*}$, Mun-Jik Lee ${ }^{\oplus^{*}}$, Gun Rae Cho ${ }^{\circledR *}$, \\ Geonhui Ki®*, Min-Gyu Kim $\circledast^{*}$ and Ji-Hong Li®* \\ "Marine Robotics RED Division, Korea Institute of Robot and Convergence, Pohang, Korea

\section{URI-T, 해저 케이블 매설용 ROV 트렌처 개발 및 실해역 성능 검증}

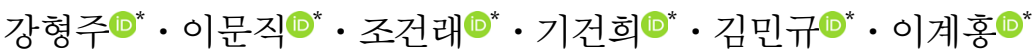 \\ "한국로봇융합연구원 해양로봇연구본부
}

KEY WORDS: ROV(Remotely operated vehicle) trencher 원격무인잠수정 타입의 트렌처, Sea floor cable burying 해저케이블 매설, PLIB(Post lay inspection and burial), Hydraulic system 유압 시스템, Water jet system 워터젯 시스템

\begin{abstract}
An ROV trencher is a type of heavy-duty work class ROV equipped with high-pressure water jet tools for cutting into the sea floor and burying cables. This kind of trencher is mostly used for PLIB operations. This paper introduces the development of this kind of ROV trencher, which has a $698 \mathrm{~kW}$ power system, with a $250 \mathrm{~kW}$ hydraulic system and two $224 \mathrm{~kW}$ water jet systems. The project was launched in January 2014. After four years of design, manufacturing, and system integration, we carried out two sea trials near the Yeongilman port (about 20-30 $\mathrm{m}$ in depth) in Pohang to evaluate the system performance in November 2017 and August 2018. Through tests, we found that most of specifications were satisfied, including a maximum bury depth of $3 \mathrm{~m}$, maximum bury speed of $2 \mathrm{~km} / \mathrm{h}$, and maximum forward speed of $1.54 \mathrm{~m} / \mathrm{s}$.
\end{abstract}

\section{1. 서 론}

해양환경은 사람의 직접적인 접근이 제한되는 공간으로써, 다양 한 분야에서 다양한 형태의 수중로봇을 활용한 작업이 이뤄지고 있다(Christ and Wernli, 2014). 그 중 한 분야인 해저 케이블 매설 분야는 육지와 도서 간의 전력 공급 및 통신 연결을 위해 해저에 케이블을 설치하는 작업을 포함한다. 해저에 설치된 케이블은 어선 의 앵커와 같은 조업 도구, 트롤 어선의 전개판 등의 인위적 위험 요소와 지진, 태풍 등의 자연적 위험 요소로부터 항시적으로 노출되 어 있다. 이러한 이유로 해저 케이블의 경제성 및 안정성을 위해서는 최적의 케이블 보호공법이 필수적으로 적용되어야 한다(Jones and Hirai, 2001; Yoo and Shin, 2010). 다양한 케이블 보호공법 중 케이블 매설 방법이 있다(Ahn et al., 2011). 이는 케이블을 포설과 동시에 매설하는 방법과 사전에 포설된 케이블을 매설하는 방법(Post lay inspection and burial, PLIB)으로 나뉘는데, 케이블 매설 위치, 해저 지형 등에 따라 선택적으로 사용된다(Mole et al., 1997).

다양한 수중건설로봇이 소수의 국외기업이 독과점하고 있는 상
황에서 국내 수중건설로봇 분야의 기술력 확보 및 경쟁력 향상을 위해 2013년 해양수산부는 해양 구조물 건설을 위한 수중건설로봇 개발과 성능 검증을 위한 인프라구축을 목표로 수중건설로봇사업 단(Underwater Construction Robotics R\&D Center, UCRC)을 발족했 다(Jang, 2014). 이를 통해 해외기술 수입 대체효과 및 유사기술 수출을 통한 외화 수입 효과를 기대하고 있다. 해당 사업단은 3 개 의 R\&D 프로젝트와 1개의 인프라 구축 프로젝트를 수행하고 있고, 본 논문에서 소개될 ROV 트렌처는 두 번째 R\&D 프로젝트로써, PLIB 방법을 이용한 ROV(Remotely operated vehicle) 기반 수중 중 작업용 로봇이다( $\mathrm{Li}$ et al., 2014). 해당 로봇은 최대 $2,500 \mathrm{~m}$ 수심의 해저 환경에서 케이블 및 소구경 파이프라인의 매설 및 유지보수 작업을 수행하는 수중 중작업용 ROV 트런처로써, URI-T (Underwater Robot. It's Trencher)라고 불린다(Fig. 1).

URI-T는 효율적인 작업과 최적의 케이블 매설을 위해 Table 1 의 목표 성능이 요구되어지며, 이를 위해 $250 \mathrm{kw}$ 의 유압 시스템 과 $2 \times 224 \mathrm{kw}$ 의 워터젯 시스템이 설계되어있다. 2017년도에 전체 시스템 통합이 이뤄졌고, 당해년도 11월과 2018년도 8월에 영일

Received 13 February 2019, revised 31 May 2019, accepted 13 June 2019

Corresponding author Hyungjoo Kang: +82-54-279-0461, hjkang@kiro.re.kr ORCID: https://orcid.org/0000-0001-8838-3285

It is a recommended paper from the proceedings of 2018 autumn workshop of the Korea Marine Robot Technology (KMRTS) which is one of the divisions belong to the Korean Society of Ocean Engineers (KSOE). 


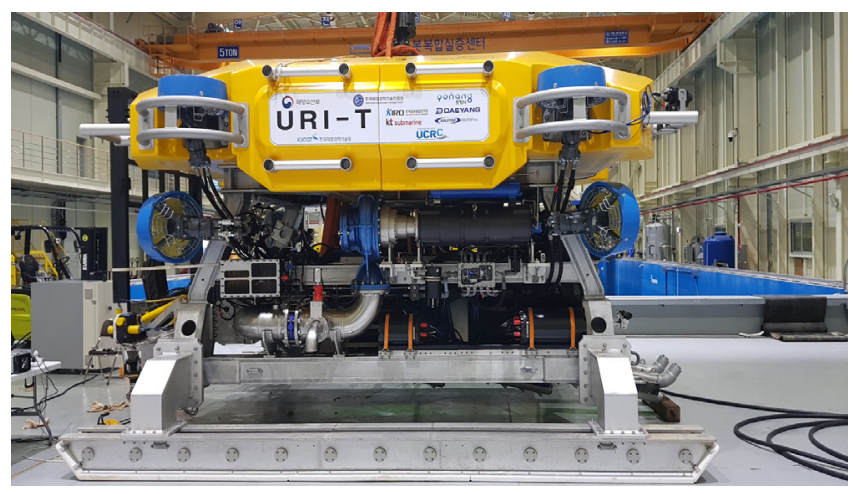

Fig. 1 URI-T, Underwater heave-duty ROV trencher

Table 1 URI-T's target and verified specifications

\begin{tabular}{lll}
\hline \hline \multicolumn{1}{c}{ Item } & \multicolumn{1}{c}{ Target } & Verification \\
\hline Working depth & Max. $2,500 \mathrm{~m}$ & - \\
Burying depth & Max. $3 \mathrm{~m}$ & $3 \mathrm{~m}$ \\
Burying speed & Max. $2 \mathrm{~km} / \mathrm{hr}$ & $2.36 \mathrm{~km} / \mathrm{hr}$ \\
Forward Speed & Max. $1.54 \mathrm{~m} / \mathrm{s}$ & $1.7 \mathrm{~m} / \mathrm{s}$ \\
Payload & $\leq 500 \mathrm{~kg}$ & $\leq 540 \mathrm{~kg}$ \\
\hline
\end{tabular}

만신항 남방파제 근처에서 두번의 실해역시험을 수행하였다. 실해역 시험 및 추가적인 육상실험 결과 모두 목표사양을 만족 함을 3장에서 확인할 수 있었다(Table 1).

본 논문에서는 개발된 URI-T의 전반적인 시스템에 대해 설명 하고, 실해역 실험과 육상에서의 추가 실험을 통해 도출된 실험 결과를 기술함으로써, URI-T의 성능을 검증하고자 한다. 2장에 서 URI-T전체적인 시스템 개요에 대하여 설명하였고, 3장에서 두 번의 실해역 실험과 육상에서의 추가 실험 방법 및 결과 등 을 자세하게 소개하고, 끝으로 4장에서 결언 및 향후계획에 대 하여 언급하면서 논문을 마무리 하고자 한다.

\section{2. 시스템 개요}

\section{1 일반사양}

URI-T의 상세 사양은 아래의 Table 2에 표시하였다.

ROV트렌처의 인터페이스 및 내부 네트워크는 EtherCAT을 이 용해 구성되어져 있다(Kang et al., 2016). URI-T는 크게 유압 시 스템, 워터젯 시스템, 선상원격제어 시스템, 선상전원공급 시스 템, 유압기반 케이블 작업공구, 매니플레이터 시스템으로 나뉘 며, 이어지는 장에서 상세히 설명한다.

\section{2 유압 시스템}

URI-T는 $250 \mathrm{~kW}$ 의 Hydraulic powered unit(HPU)을 이용하여 로봇의 모션 및 위치를 제어하고, 매설 및 유지보수 작업을 위 한 장비를 구동시킨다.

Fig. 2의 유압 회로도에서 보여지듯이, HPU를 이용해 모든 유 압 장비에 유량을 공급하고, 4 대의 유압 밸브팩을 통해 유압 장 비를 제어한다. 장비의 종류에따라 추진기 및 작업툴용 밸브팩 으로 나뉜다. 유압 장비로는 HPU를 포함하여, 추진기 8대(수평 추진기 4대, 수직 추진기 4대)(Li et al., 2014), 매니플레이터 2대 (5축, 7축), 작업툴(커터, 그리퍼), 유압실린더 6대(TSS 핸들러 2 개, 젯팅암 4개)가 있다. 여기서, 매니플레이터와 작업툴은 케이 블의 유지보수를 위한 장비로써, 해저에서 매니플레이터를 이 용해 작업툴을 사용한다. 그리퍼를 이용해 파손된 케이블을 잡 고 커터를 이용해 그립된 케이블을 자른다. TSS 핸들러는 케이 블 탐지 시스템인 TSS440을 활용하기 위한 일종의 지그로써, 활용 유무에 따라 접거나 펼칠 수 있다.

\section{3 워터젯 시스템}

워터젯 시스템은 직접적으로 매설작업이 진행되는 부분으로 $224 \mathrm{kw}$ 워터펌프 2대(좌현 1대, 우현 1대), 모션베이스, 젯팅암 2 대(좌현 1대, 우현 1대)로 이루어진다(Fig. 3). 여기서, 워터펌프 는 선상전원공급 시스템으로부터 전력을 공급받아 구동되며,

Table 2 URI-T's specifications

\begin{tabular}{lll}
\hline \hline & \multicolumn{1}{c}{ Item } & \multicolumn{1}{c}{ Specification } \\
\hline Size & & $6.6(L) \times 4.5(W) \times 3.5(H) \mathrm{m}$ \\
Weight & About $21 \mathrm{t}$ \\
\multirow{2}{*}{ Hydraulic system } & Thruster & $250 \mathrm{~kW}, \mathrm{RiSEA}$ \\
Water jet system & Water-Pump & $10535 \mathrm{~N}, 835 \mathrm{RPM}$, RiSEA \\
& IMU (inertial measurement unit) & $224 \mathrm{kw}, 986 \mathrm{~m} / \mathrm{hr}$ \\
& DVL (doppler velocity log) & HG1700AG37, Honeywell \\
& Depth & WHN600K3, Teledyne \\
Navigation & Multibeam sonar & Series8000, Paroscientific \\
& Cable detection system & M900-250, Blueview \\
& USBL (ultra-short baseline) & TSS350\&440 ${ }^{1)}$, Teledyne \\
\hline
\end{tabular}

1) TSS는 Subsea pipe \& Cable tracking system으로 운용방식에 따라 350과 440으로 나뉜다. 350은 Pulse induction 기술을 이용하여 자기장을 검출하는 방식이고, 440 은 Tone pulse를 검출하는 방식이다. URI-T에는 350,440 을 Dualtrack으로 하여 탐지성능을 극대 화하였다. 


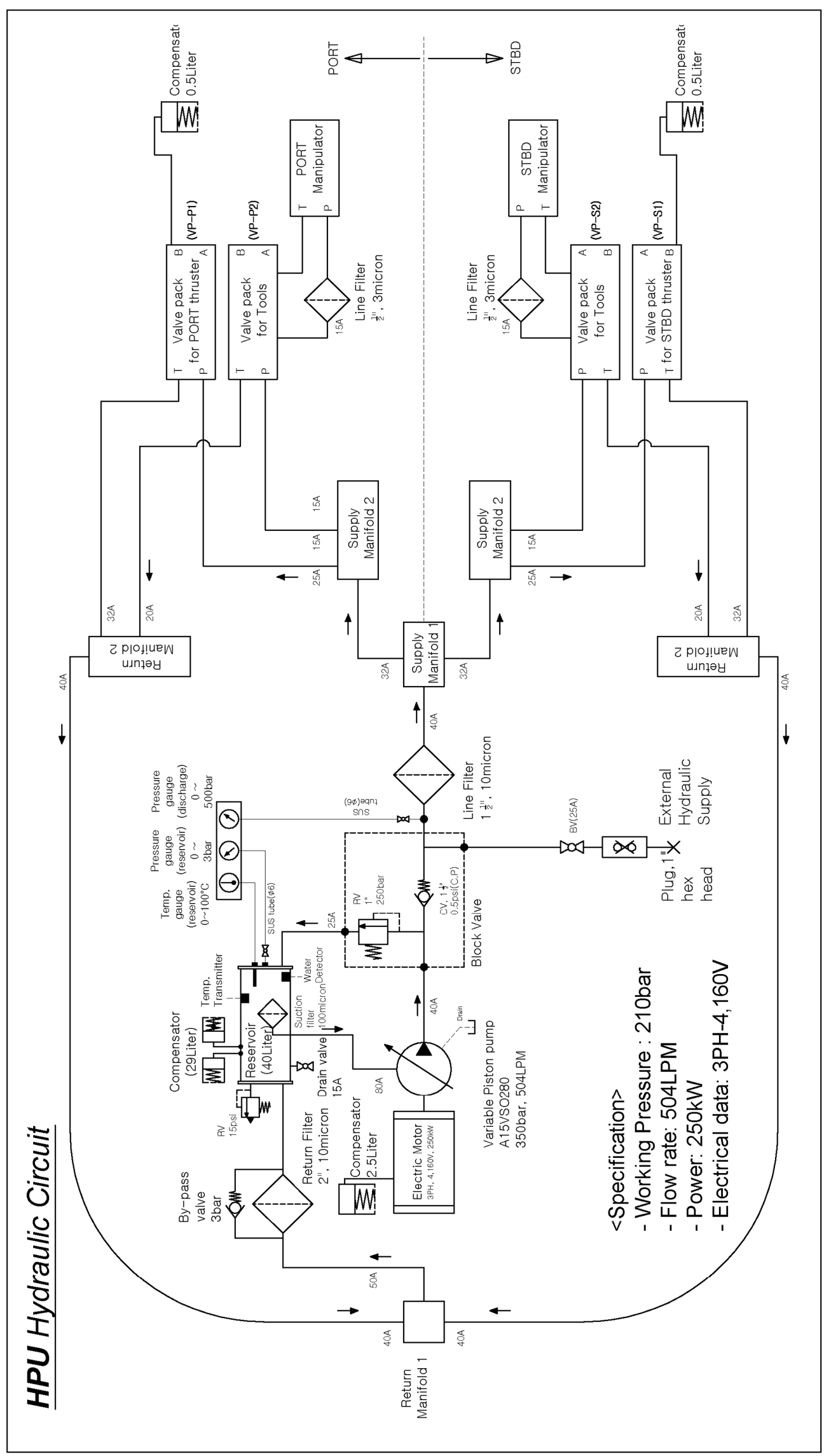

Fig. 2 HPU hydraulic supply circuit diagram 


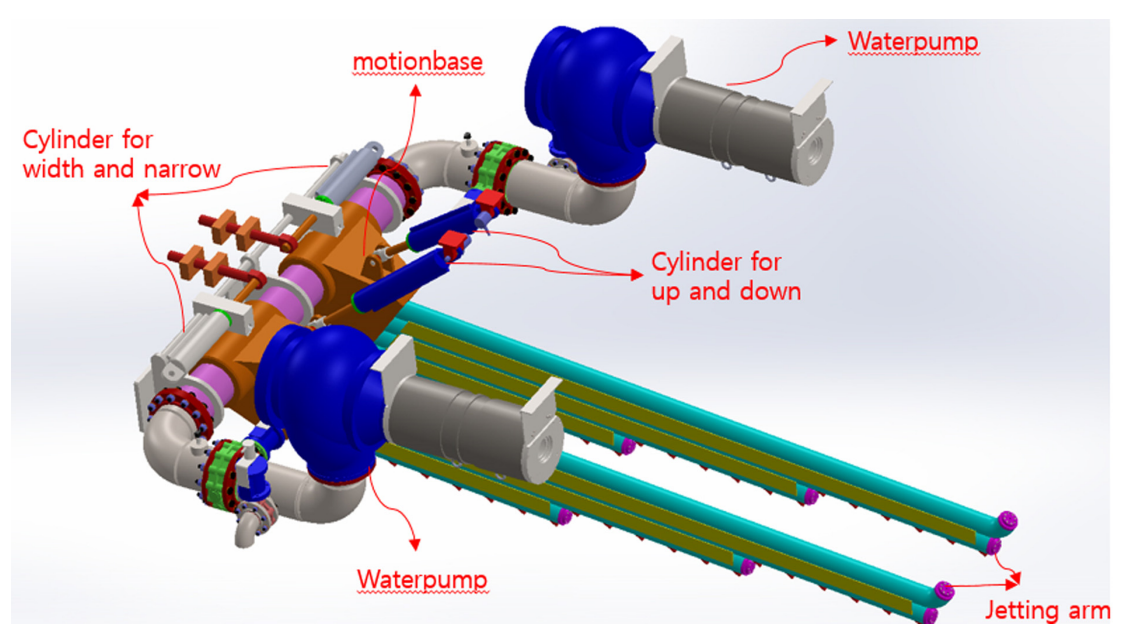

Fig. 3 3D blueprint for Water jet system
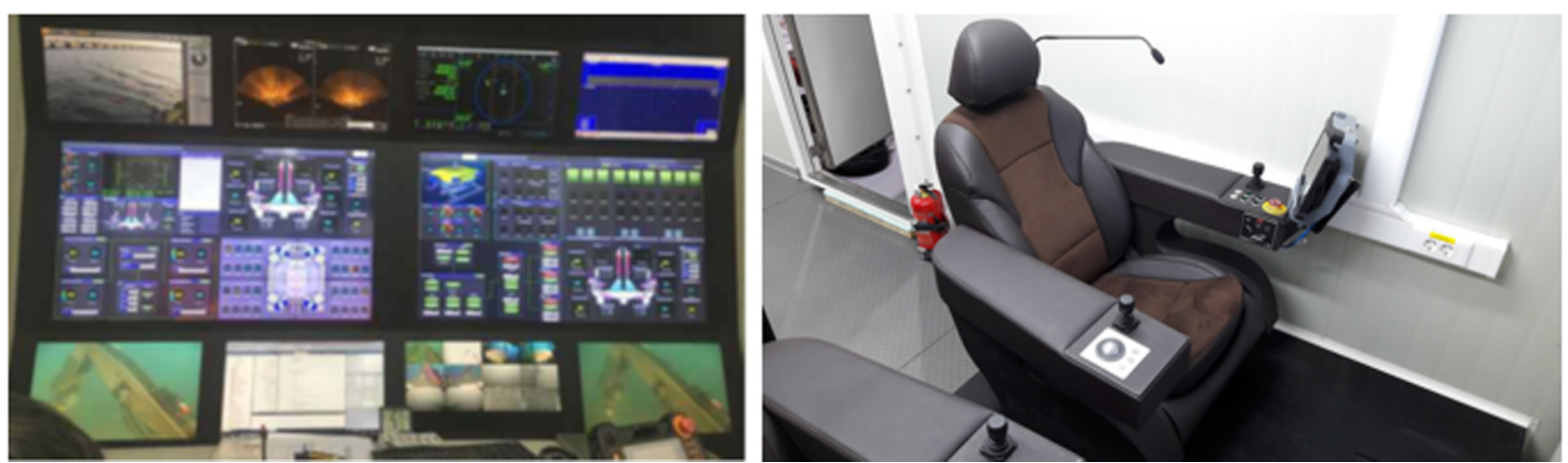

Fig. 4 Equipment in Surface remote control system (Left: Monitorwall, Right: console chair and touch screen for control)

선상원격제어 시스템에서 $0 \sim 60 \mathrm{hz}$ 로 유량을 조절한다. 모션베이 스는 4개의 유압실린더(좌/우, 상/하 조절 실린더)로 구성되어져 있으며, 각각은 2 대의 젯팅암 위치를 조절할 때 사용된다. 젯팅 암은 물이 분사되는 노즐이 있는 부분으로, 해저면으로 워터젯 을 직접 분사한다. 각각 좌 - 우로 $0.2 \mathrm{~m}$ 에서 $0.7 \mathrm{~m}$ 까지 조절가능 하고, 상-하로는 스키드(URI-T에서 바닥에 닫는 부분)를 기준 으로 해저면 아래로 최대 $3.0 \mathrm{~m}$ 까지 펼칠 수 있다(Li et al., 2015; $\mathrm{Na}$ et al., 2015).

\section{4 선상원격제어 시스템}

선상원격제어 시스템은 특수제작된 선상제어용 컨테이너안에 서 ROV 트렌처의 상태를 확인하고, 제어하는 등 매설 업무를 원활히 수행하기 위해 제작된 시스템이다. 밴 내부는 전원 및 통신 분배반, 모니터월(Fig. 4의 좌측 사진), 2대의 콘솔체어 및 제어용 터치 스크린(Fig. 4의 우측 사진)으로 구성된다. 모니터 월은 42 인치 모니터 2대와 21.5 인치 모니터 8 대로 구성되어져 있으며, ROV트렌처의 상태 관측에 사용된다. 콘솔체어에는 조 이스틱, 조그 다이얼, 버튼이 부착되어져 있으며, ROV 트렌처 의 모션 및 위치를 조절하고, 전원 상태 변경에 사용된다. 제어 용 터치 스크린은 ROV의 상세 상태 설정을 위한 터치 GUI (Graphical user interface)를 내장하고 있다.

\section{5 선상전원공급 시스템}

선상전원공급 시스템은 특수제작된 전원공급용 컨테이너 2대
로 구성되어져 있다. 이는 모선으로부터 제공받는 전원을 ROV 트렌처의 내부 전원, HPU 전원, 2 대의 워터펌프 전원에 안정적 인 전력을 공급한다.

2.6 유압기반 케이블 작업공구

유압기반 케이블 작업공구로는 그리퍼와 커터가 있다. 그리퍼 와 커터는 URI-T 전방에 있는 거치대에 보관되어 있는데, 케이 블 유지보수 작업 시에 매니플레이터에 의해 사용된다. 그리퍼 는 17 110mm의 케이블을 25톤의 힘으로 움켜잡을 수 있다. 커 터는 최대 $110 \mathrm{~mm}$ 의 케이블을 커팅할 수 있고, 이때의 최대 커 팅 압력은 $69 \mathrm{mPa}$ 이다. 각각 Fig. 5-6에 이미지를 도시한다.

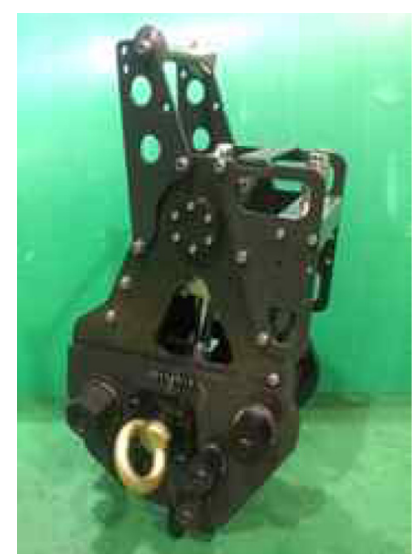

Fig. 5 Gripper

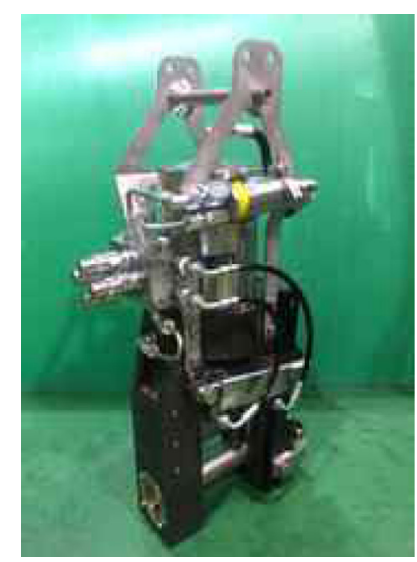

Fig. 6 Cutter 


\section{7 매니플레이터 시스템}

매니플레이터 시스템은 수중에서 작업공구를 사용하기 위해 사 용되며, 2대의 유압 매니플레이터(Fig. 7), 2대의 압력보상기, 운용 펜던트로 구성된다. 매니플레이터는 $10-21 \mathrm{mPa}$ 의 압력에서 구동되 어 진다. 수중에서의 압력을 보상해주기 위해 압력보상기가 각각 설치되어져 있다. 선상원격제어 시스템 내부에서 운용하기 위해 별도의 운용 펜던트가 있으며, 전용 소프트웨어를 이용해 운용된다.

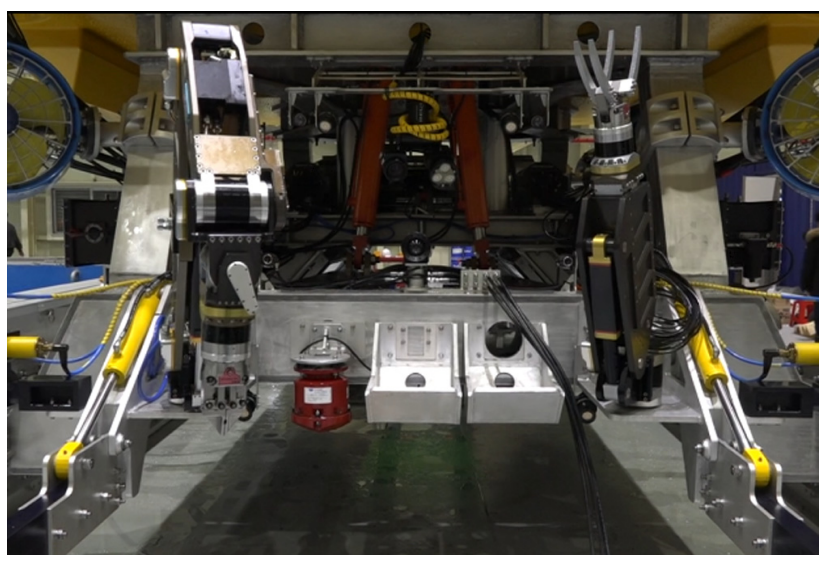

Fig. 7 Manipulators amounted URI-T (Left: 7 axis, Right: 5 axis)

\section{3. 실해역 시험을 통한 성능검증}

앞서 언급한 바와 같이 URI-T의 성능 검증을 위해 2 번의 실 해역 실험과 1 번의 육상 실험을 진행하였다. 현장 실험의 경우, 날씨, 비용, 선박, 실험장소 등의 사항을 고려하여 진행하였다.

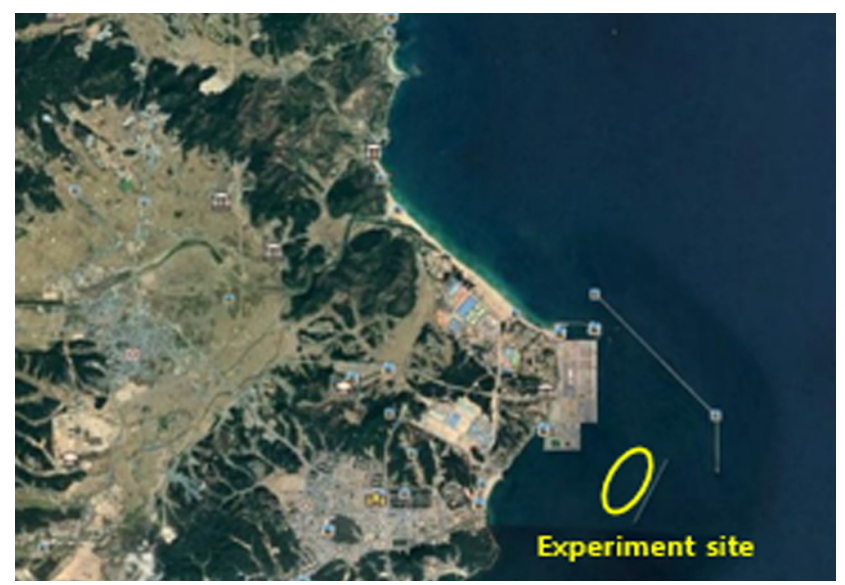

Fig. 8 Site for sea trial

Table 3 URI-T's time table for sea trial

\begin{tabular}{|c|c|c|}
\hline Test & Schedule & Verified item \\
\hline The first sea trial & $\begin{array}{c}\text { 2017.11.27-2017.12.09 } \\
\text { (13 days) }\end{array}$ & Burying speed \\
\hline Test for burying depth & 2018.02.27 (1 day) & Burying depth \\
\hline The second sea trial & $\begin{array}{l}2018.08 .04-2018.08 .11 \\
(8 \text { days })\end{array}$ & $\begin{array}{l}\text { Burying depth, } \\
\text { Burying speed, } \\
\text { Forward speed }\end{array}$ \\
\hline Test for payload & 2018.11.22 (1 day) & Payload \\
\hline
\end{tabular}

실해역 실험은 경상북도 포항시 영일만항의 남쪽 방파제 앞쪽 에서 진행되었고 수심은 최대 20 30m정도이다. 육상 실험 역시 실해역 실험 장소 근처의 공터에서 진행되었다. 실험장소와 일 정은 Fig. 8와 Table 3에 표시하였다. 상세한 실험 내용은 시행 된 시간 순서에 따라 설명한다.

\subsection{1차 실해역 시험}

본 실험에서는 URI-T의 전반적인 시스템 성능을 점검하고 운 용 성능을 검증하고자 하였다. 실험은 실제 ROV 트렌처의 운용 시나리오와 유사하며, 여러 제약사항으로 인해 일부 수정하여 진 행하였다. Fig. 9과 Fig. 10에는 실험 시나리오의 개념도와 URI-T 를 포함한 실험 장비들의 갑판 배치도를 도시하였다. URI-T는 바 지선에서 운용되며, 250 톤급 크레인을 이용해 진 - 회수된다(실 제 운용에서는 전용 진·회수 시스템 ${ }^{1)}$ 및 엄빌리컬 윈치를 이 용). 바지선은 예인선에 의해 이동되며, 2,100 톤급 적재 용량과 길이 $48 \mathrm{~m}$, 폭 $20 \mathrm{~m}$ 의 크기를 가진다. $100 \mathrm{~kW}, 1,000 \mathrm{~kW}$ 급 발전기 (Genset)를 이용하여 각각 선상원격제어 시스템과 선상전원공급 시스템으로 전원을 공급한다. 바지선의 여건상 윈치 시스템을 활 용하기 어려워, 엄빌리컬 케이블을 다루기 위한 케이블 핸들링 시스템 ${ }^{3)}$ 을 별도로 구성하였다. Fig. 9의 시나리오를 상세히 설명 하자면, 예인선을 이용해 매설용 케이블을 해저면에 설치하고, 잠수사를 통해 포설 상태를 확인한다. 그리고 크레인을 이용해 URI-T를 진수시키고, URI-T의 위치에 따라 케이블 핸들링 시스 템을 이용해 엄빌리컬 케이블의 길이를 조절한다. URI-T가 해저 면에 안착한 후, 케이블 탐지 시스템을 이용해 포설된 케이블의 위치를 확인하고, URI-T를 그 위로 이동시킨다. URI-T는 워터젯 시스템을 이용하여 케이블을 매설하고, 매설 지역을 따라가며 매 설 상태를 확인한다. 요구되는 매설 심도가 나올때까지 매설 및 매설 상태 확인 작업을 반복한다. 매설이 완료되면 URI-T를 회수 한다.

본격적인 매설 실험을 수행하기 전에, 기존 수조 실험에서 전 력 및 공간적 제약으로 진행하지 못한 URI-T 개별 시스템에 대 한 성능 점검을 진행하였다. 워터젯 시스템 성능 실험에서 워터 펌프가 최고 출력 $(60 \mathrm{hz})$ 으로 구동될 때, 전원 노이즈로 인해 모 션베이스 제어보드(작업툴용 밸브팩)가 이상 동작함을 확인하 였고, 제어보드에 노이즈 필터를 추가하여 해당 문제를 해결하 였다. 그리고 워터젯이 분사될 때, 해저면의 부유물이 일어 카 메라 시야확보가 어려워, 멀티빔소나를 이용하여 전방 및 후방 의 장애물, 매설 정도를 관측하고, USBL을 이용해 URI-T의 위 치 및 이동 경로를 확인하였다. 유압 시스템 성능 실험에서 추 진기를 구동할 때, 해저면 근처에 버려진 폐로프가 추진기 가드 에 걸려 제대로 작동하지 않아, 추진기 가드를 교체하였다.

URI-T의 모든 시스템이 정상 동작함을 검증한 후, 운용 성능 검증을 위해 케이블 매설 시나리오에 따라 실험을 진행하였다.

1) 일반적으로 Launch and recovery system(LARS)으로 불리며, A-frame 이라는 장비를 이용해 진 · 회수한다.

2) 엄빌리컬 케이블은 ROV와 선상 시스템을 연결하는 케이블로써, ROV로 전원을 공급하고 통신을 연결한다. 케이블 손상을 방지하기 위한 아머가 설치되어 있다. 엄빌리컬 윈치는 선상에서 케이블을 감고 풀어주며 케이 블의 길이를 조절한다. 이를 통해 ROV를 진 · 회수한다.

3) 케이블을 당기고 풀기 위한 전자식 케이블 엔진과 케이블을 감아 보 관하는 캐러셀로 구성되어 있다. 


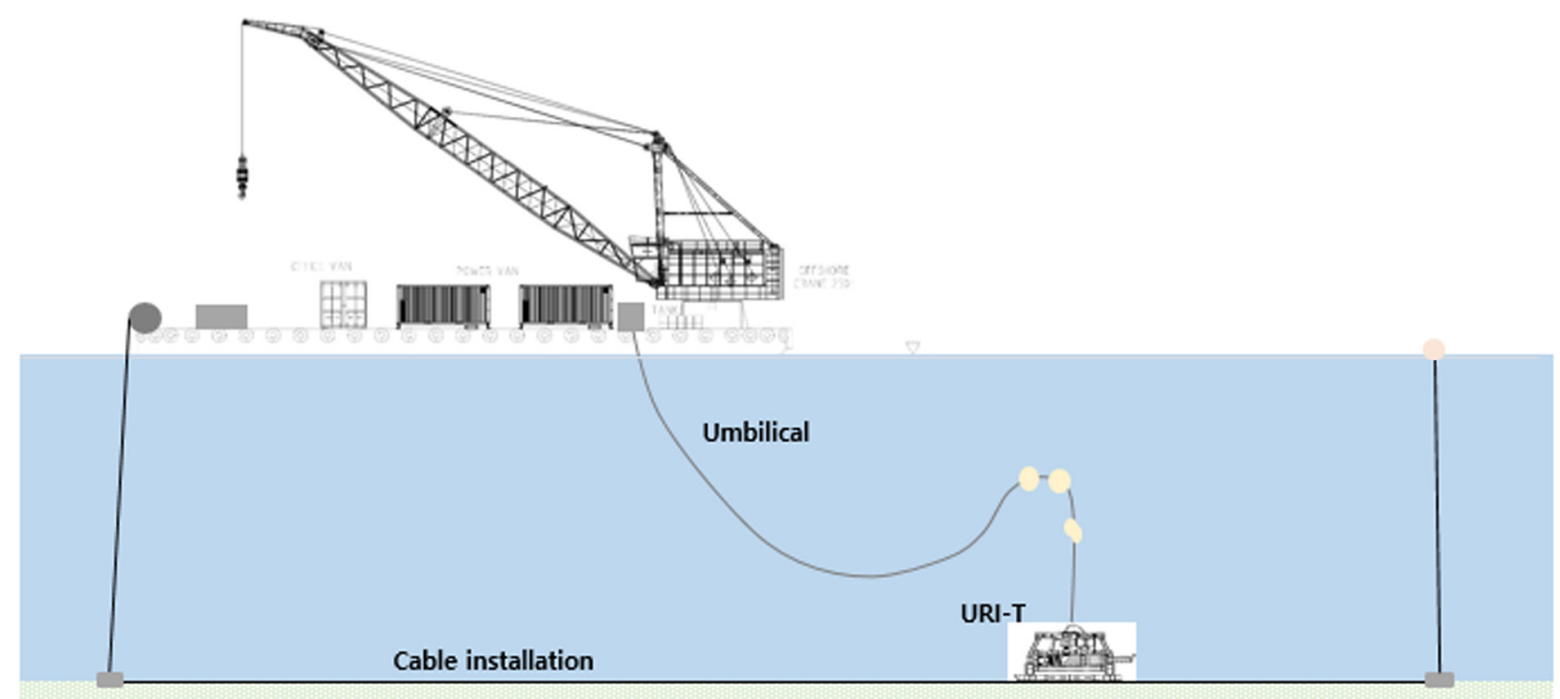

Fig. 9 URI-T's cable burying scenario concept map

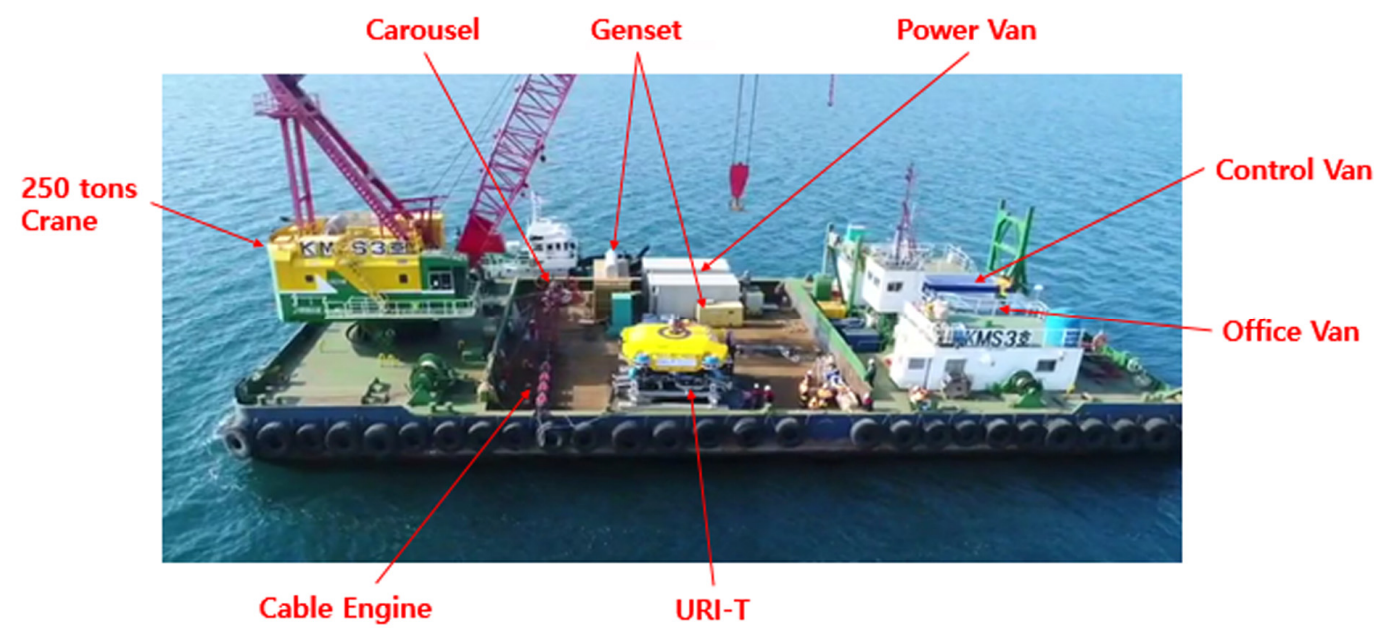

Fig. 10 Equipment arrangement plan for sea trial on the deck

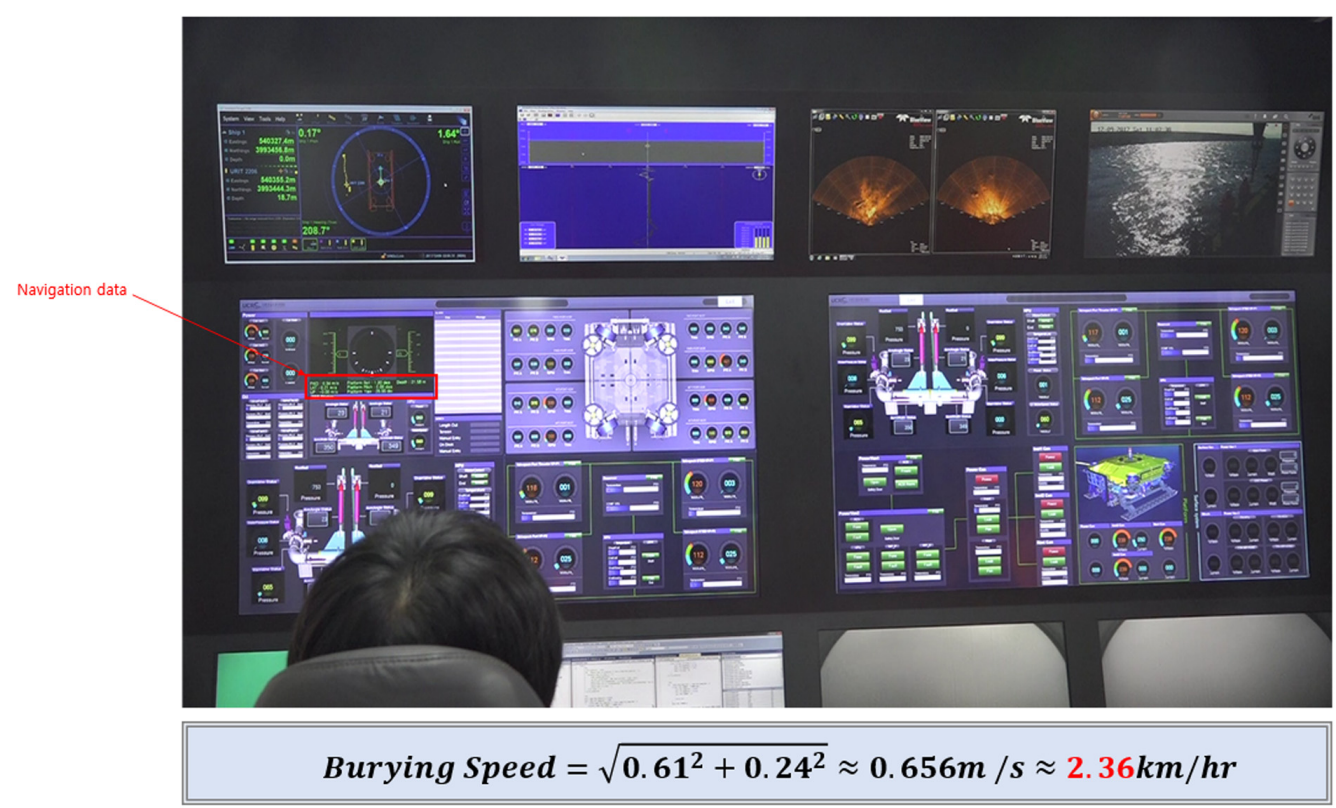

Fig. 11 Sea trial result: burying speed 

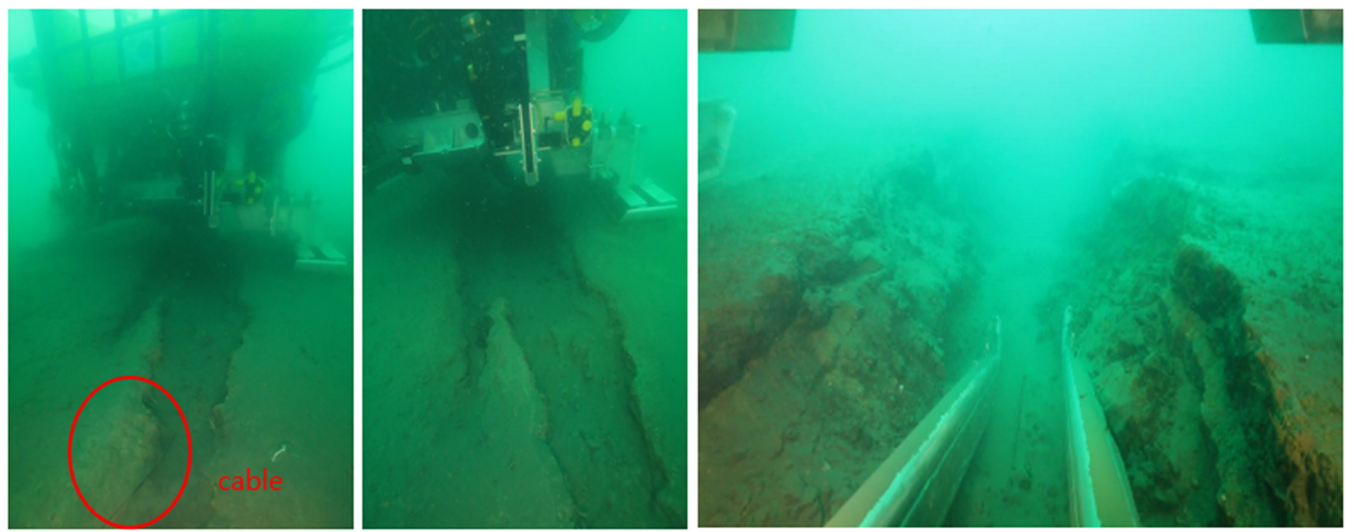

Fig. 12 The result of cable burying

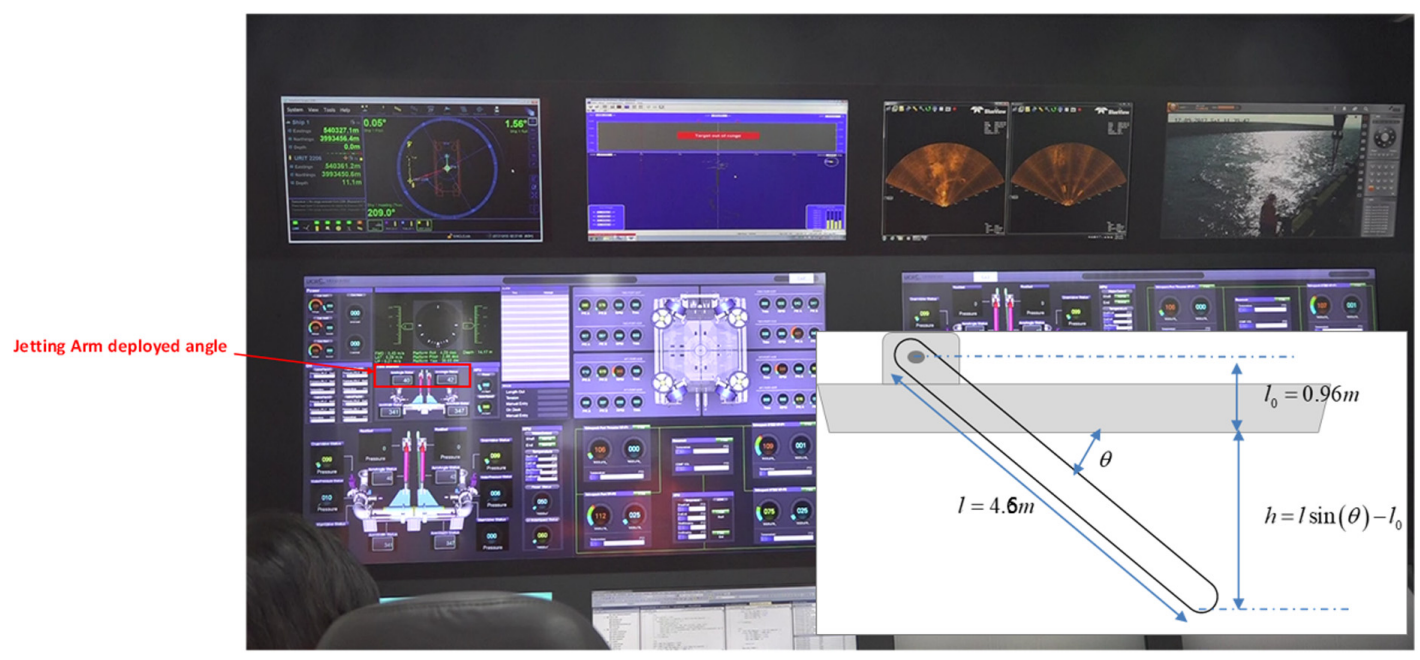

Burying Depth $=$ arm lenth $\times \sin ($ arm deploy angle $)-$ arm height from skid $=4.6 m \times \sin (40)-0.96 \approx 1.99 m$

Fig. 13 Sea trial result: burying depth
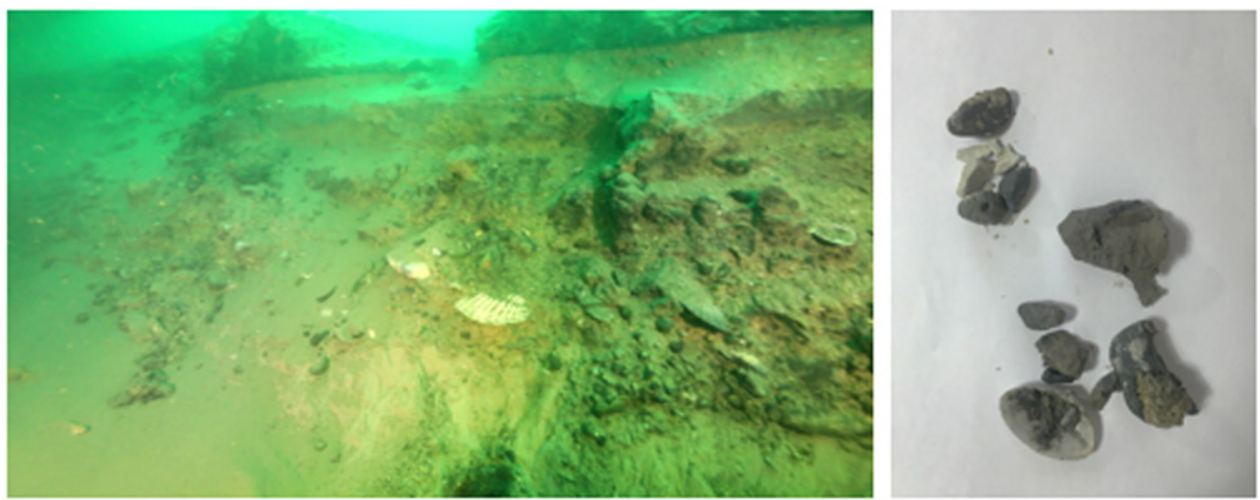

Fig. 14 The result of sea floor stratum survey

Fig. 11에서 매설 속도에 대한 실험 결과를 도시하였다. 실험 조건 은 약 $1 \mathrm{~m}$ 매설 깊이를 유지하며 약 $50 \mathrm{~m}$ 거리를 전진하였고, 해당 구간에서의 최고 속도를 계산하였다. 최고 속도는 $2.36 \mathrm{~km} / \mathrm{hr}$ 로 $2.0 \mathrm{~km} / \mathrm{hr}$ 의 목표성능을 충족함을 확인하였다. 잠수사를 이용해 촬 영된 실험 결과는 Fig. 12에 도시하였고, 케이블이 매설된 상태를 확인할 수 있다.
Fig. 13에서 매설 깊이에 대한 실험 결과를 도시하였다. 실험 조건은 특정 해저면 위에서 워터젯을 분사하며 젯팅암을 최대 한 펼치고, 그 펼쳐진 각도와 젯팅암의 길이를 이용해 매설 깊 이를 계산하였다. 계산된 최대 매설 깊이는 $1.99 \mathrm{~m}$ 로 목표 성능 $3.0 \mathrm{~m}$ 를 충족하지 못하였다. 잠수사를 통해 촬영한 실험 결과 영 상을 통해 원인을 분석한 결과, Fig. 14 와 같이 해저 지층이 뻘 


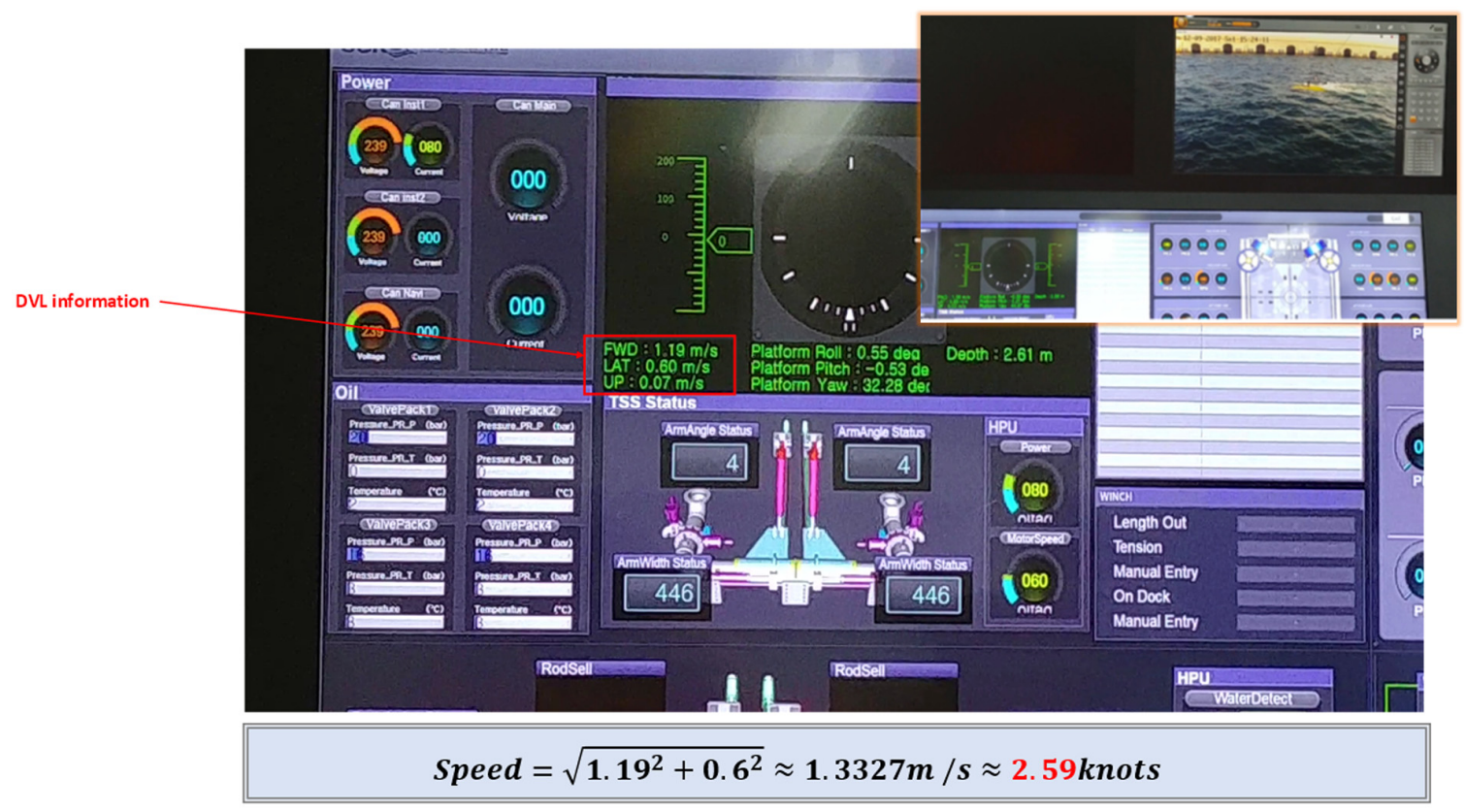

Fig. 15 Sea trial result: forward speed

과 자갈로 이뤄져 있어 충분한 매설 깊이가 나오지 않은것으로 판단하였다. 실제 URI-T는 뻘 및 자갈 지형보다 연약지반인 모 레 지형에서 운용된다.

Fig. 15에서 전진 속도에 대한 실험 결과를 도시하였다. 실험 조건은 URI-T의 상단이 수면에 위치할 정도의 양성부력을 맞춰 수평 추진기를 최대 출력으로 구동시켰다. 약 $30 \mathrm{~m}$ 구간을 이동 하였으며, DVL을 이용해 해당 구간에서의 최대 속도를 측정하 였다. 측정된 최대 속도는 $1.4 \mathrm{~m} / \mathrm{s}$ 로 계측되었고, 목표성능을 만 족하지 못하였다. 그 원인으로, URI-T의 진수를 위해 설치된 와 이어와 부이가 수면에서 저항을 발생시킨것으로 판단하였다.

실험 내용을 요약하면, 제어보드 노이즈 처리 문제, 해저 쓰 레기 문제, 시야확보 문제가 있었지만, 해당 문제를 적절히 해 결하였고, 개발된 URI-T의 시스템 성능을 검증하였다. 목표 성
능 중에서 매설 속도 항목에 대해 검증하였고, 매설 깊이 및 전 진 속도 항목은 여러 외부 여건에 의해 충족하지 못하였다. 해 당 내용은 이후의 실험에서 검증하였다.

\section{2 육상에서 최대 매설심도 실험}

앞서 언급한바와 같이, 연안에서 모래 지층을 찾을 수 있을 보장이 없고, 어민들의 민원, 공유수면 임대 등 여러 행정적인 문제로 인해 육상에서 매설 심도 실험을 대체하기로 하였다.

Fig. 16 에 육상 매설 성능 실험의 개념도를 도시하였다. 워터 펌프에 충분한 양의 물을 공급하기 위해 URI-T 양쪽에 훍으로 언덕을 만들고, 그 위에 각각 50 톤 가량의 수조를 설치하였다. 각 수조에는 워터 펌프가 동작을 할 때, 수조와 워터 펌프를 연 결하는 배관에 높은 압력이 발생할 것을 고려하여 강관으로 연

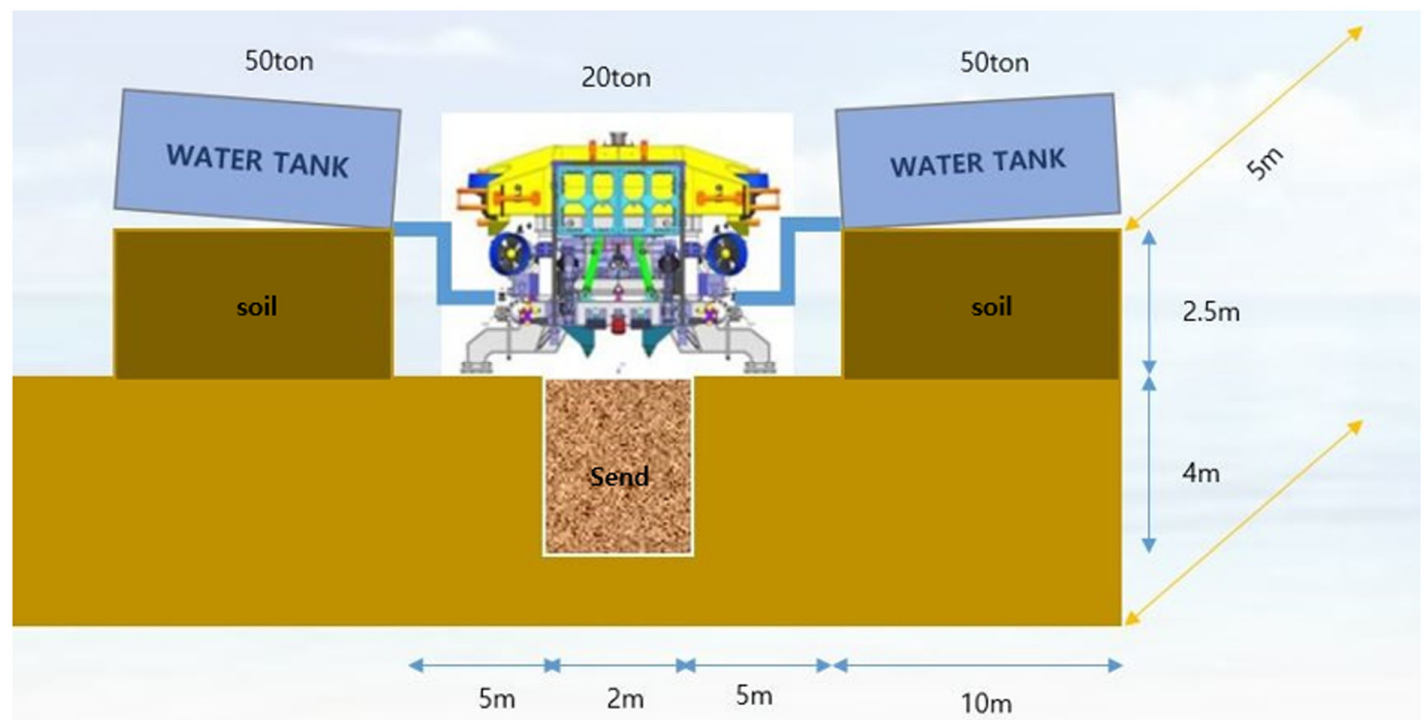

Fig. 16 concept map for burying depth performance test on the land 

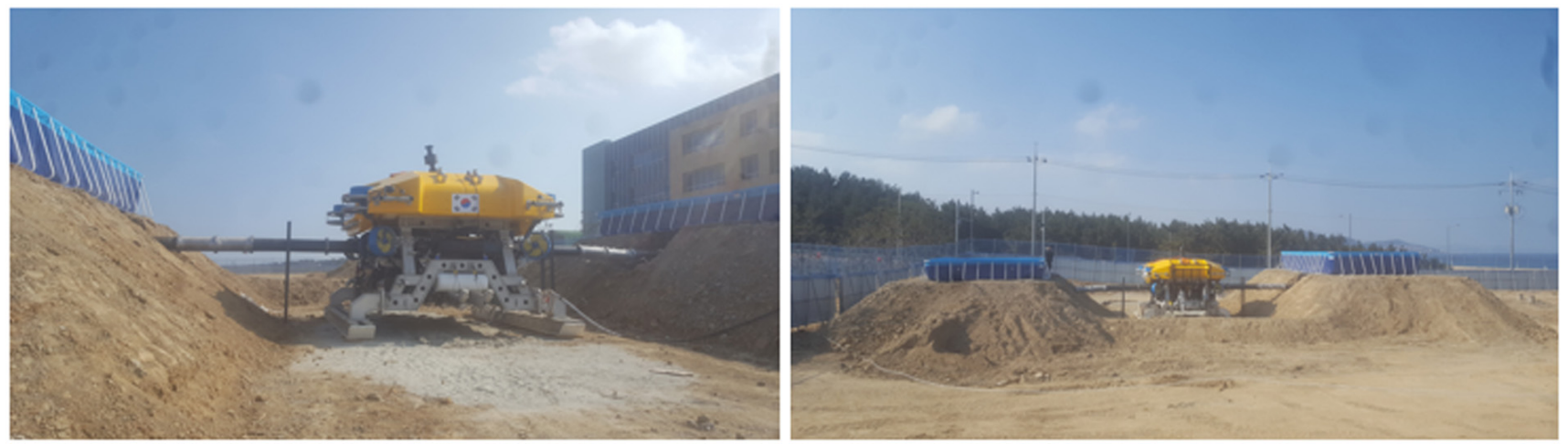

Fig. 17 Experimental field

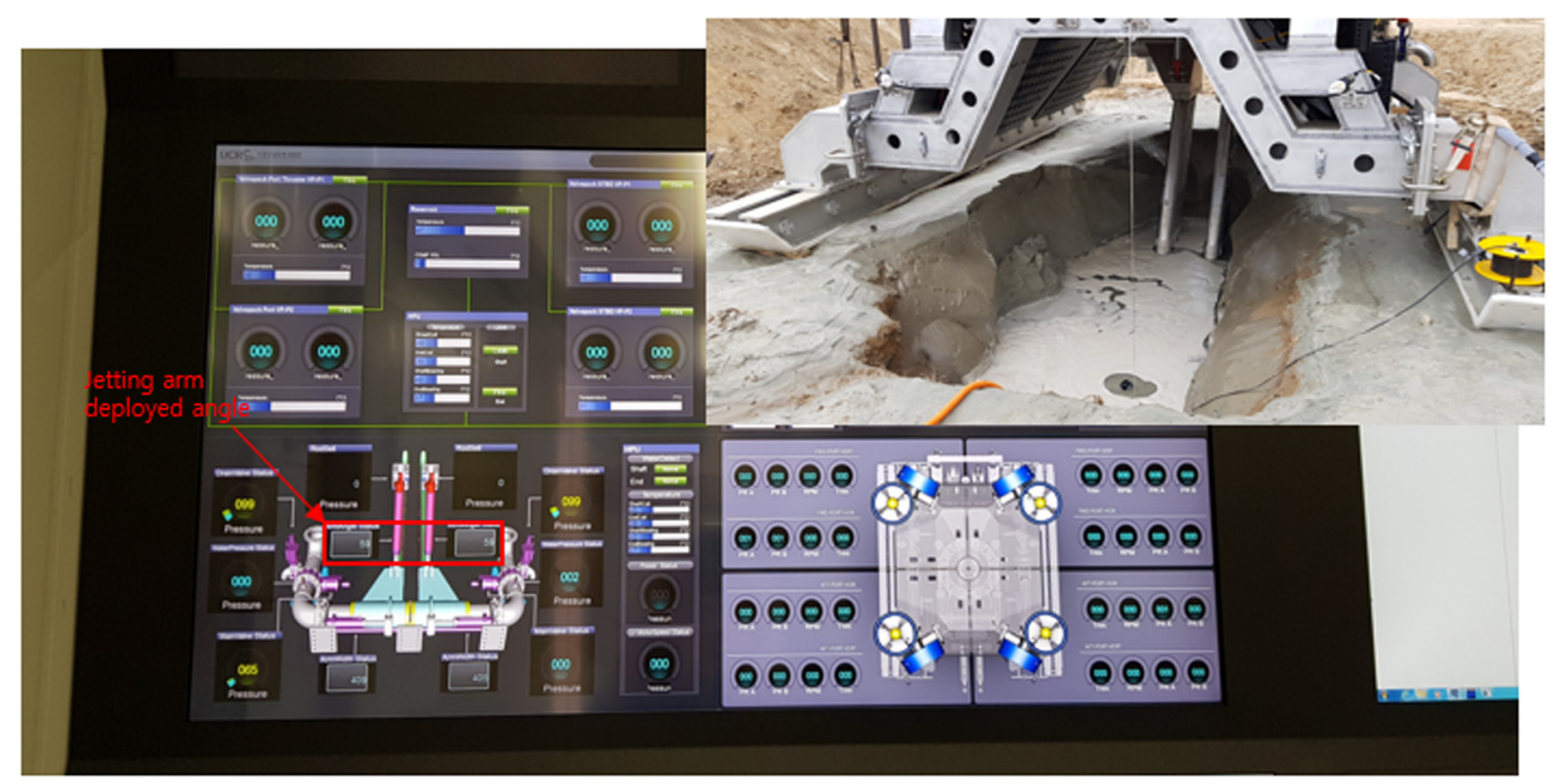

Fig. 18 The result of burying depth performance test on the land

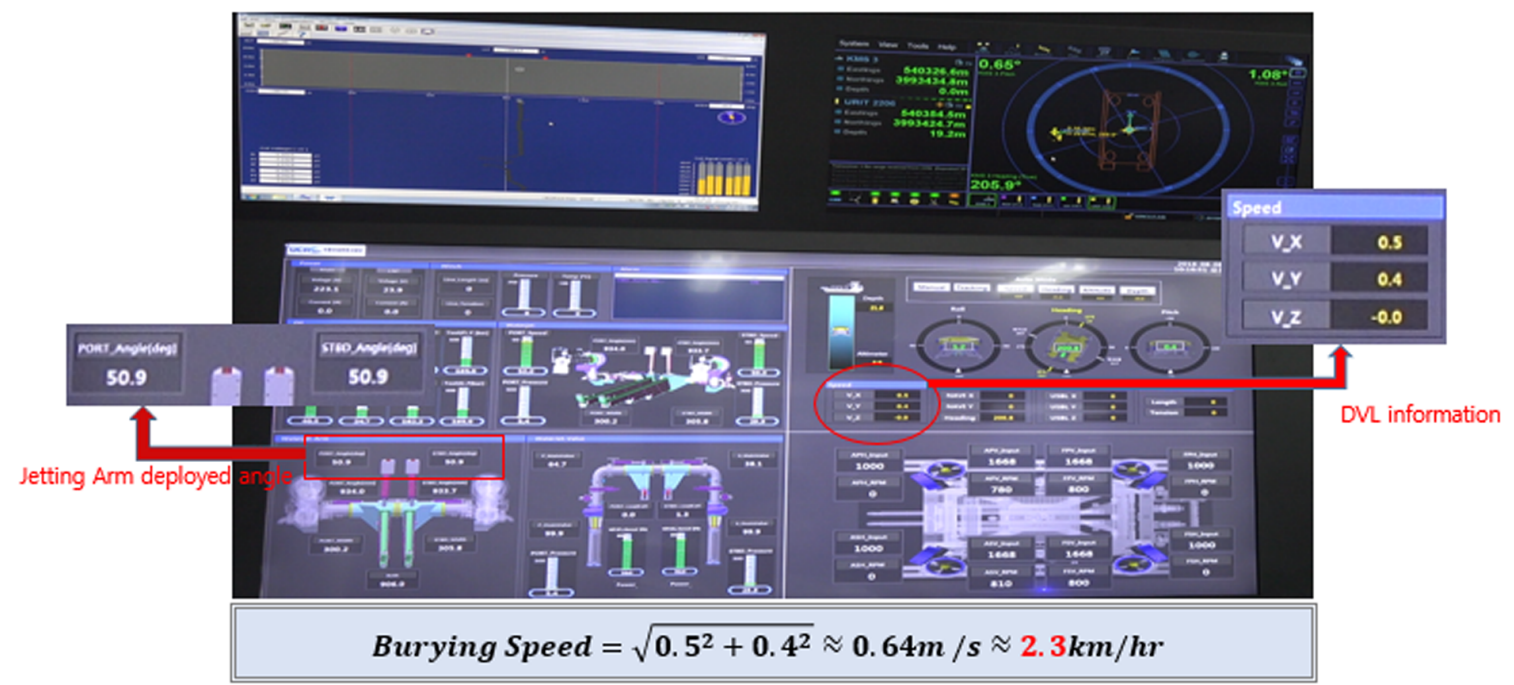

Fig. 19 Sea trial result: burying speed

결하였다. URI-T 아래에는 매설 심도, 젯팅암의 크기 및 형태를 고려하여 길이 $5 \mathrm{~m}$, 폭 $2 \mathrm{~m}$, 깊이 $4 \mathrm{~m}$ 가량의 홈을 파내고 모래로 매웠다. 그리고 전력 수급의 문제로 각각의 워터 펌프는 $50 \mathrm{hz}$ 로
구동되어 졌다. Fig. 17에 실제로 구현된 실험 현장에 대한 이미 지를 도시하였다.

실험에서 약 4 분 가량 워터젯을 분사하며 젯팅암을 하강시켰 
고, 그 결과는 Fig. 18 에 도시하였다. 젯팅암의 각도는 약 60 도 로써, 매설 깊이로 환산하면 $3.0 \mathrm{~m}$ 가 나왔다(이전 실험에 사용된 계산식을 동일하게 적용함). 이는 목표 성능 $3.0 \mathrm{~m}$ 를 충족하는 결과이다.

요악하면, 여러 제약 조건으로 인해 육상에서 매설 깊이 성능 을 검증하게 되었고, 펌프 출력 $50 \mathrm{hz}$ 의 조건(최고 출력 $60 \mathrm{hz})$ 에 서 약 4 분 안에 $3.0 \mathrm{~m}$ 매설 가능함을 검증하였다.

\subsection{2차 실해역 시험}

해당 실험을 통해, 앞서 검증된 매설 속도 및 매설 깊이 성능 을 재검증하고, 전진 속도 성능을 추가 검증했다. 실험 장소는 1
차 실해역 성능 실험지와 유사하며(방파재를 따라 남동쪽으로 약 $400 \mathrm{~m}$ 이동), 실험 준비 및 방법 역시 유사하게 진행했다. Fig. 19에 매설 속도에 대한 실험 결과를 도시하였다. $2.3 \mathrm{~km} / \mathrm{hr}$ 로 목표 성능을 충족함을 재확인했다. Fig. 20에 매설 깊이에 대 한 실험 결과를 도시하였다. 1 차 실해역 성능 실험과 달리 연약 한 해저 지층으로 조사되었고, Fig. 20에 보이는바와 같이, 매설 깊이가 $3.01 \mathrm{~m}$ 로 목표 성능이 수중에서도 충족함을 확인했다. Fig. 21에 전진 속도에 대한 실험 결과를 도시하였다. 실험은 동 일하게 진행되었고, 다만, URI-T를 크레인으로 진 · 회수 시키기 위한 고정부를 제거하여 직진시에 발생하는 외력을 최소화하였 다. 약 $30 \mathrm{~m}$ 구간을 이동하며, DVL을 이용하여 속도를 측정하였

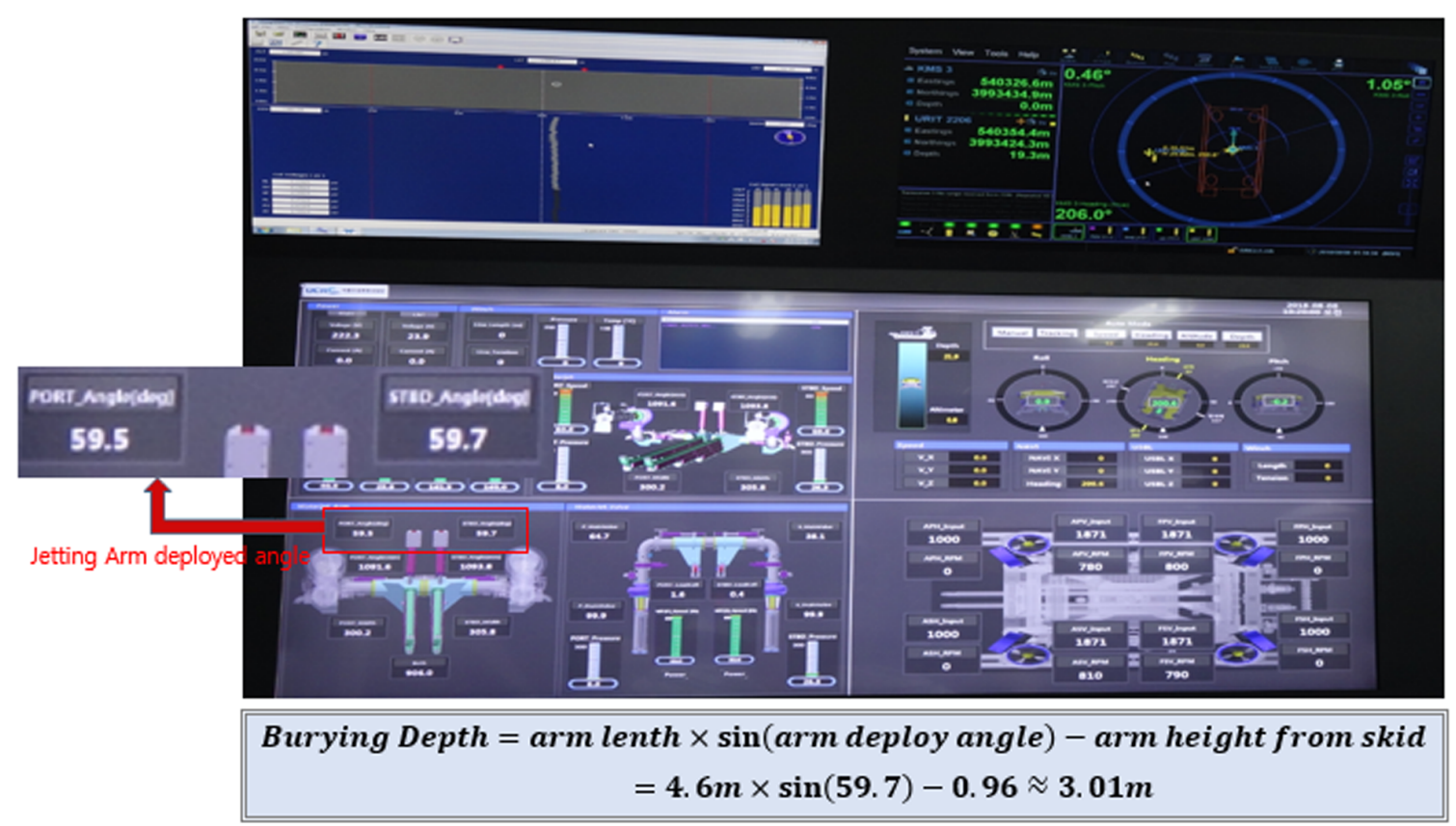

Fig. 20 Sea trial result: burying depth

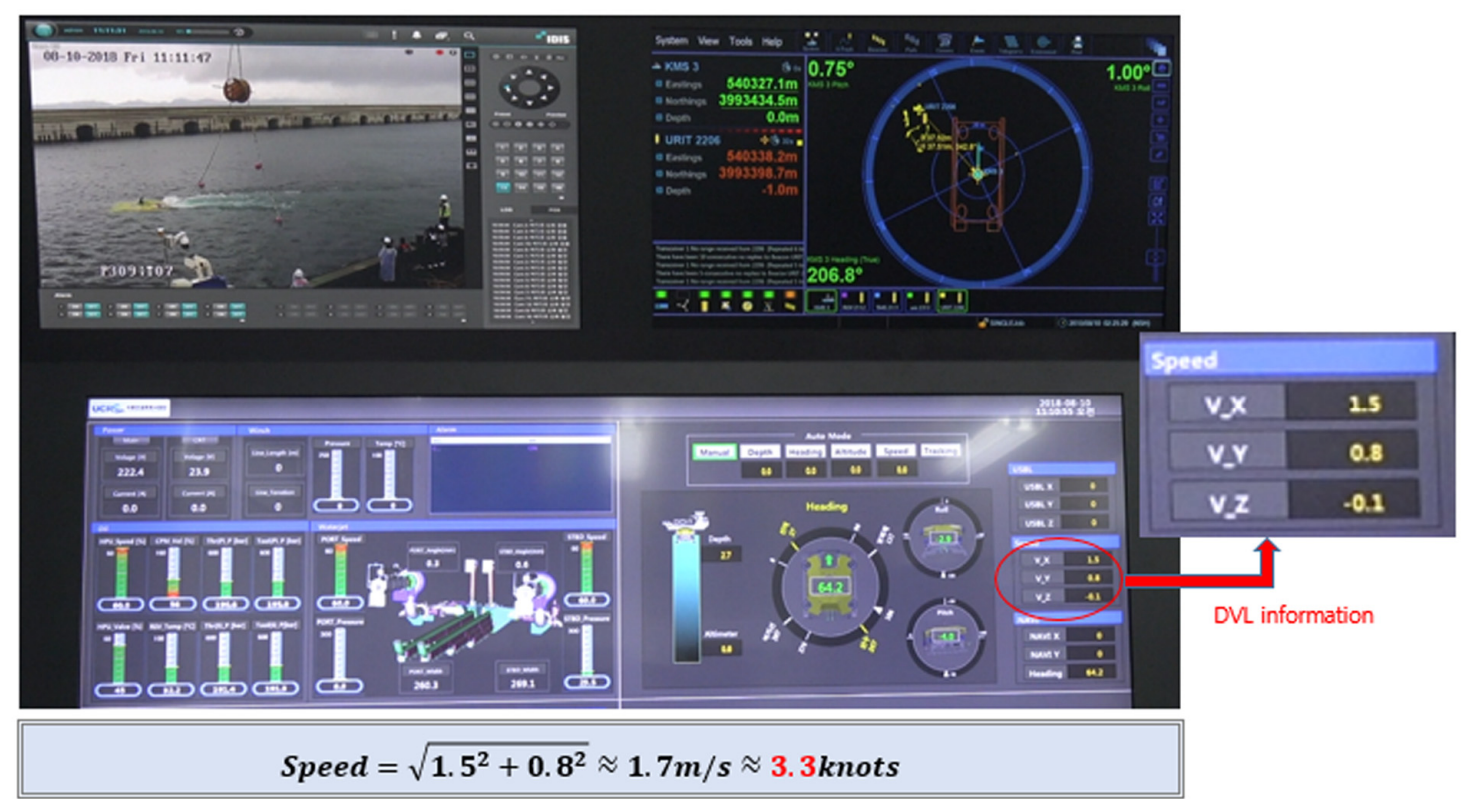

Fig. 21 Sea trial result: forward speed 


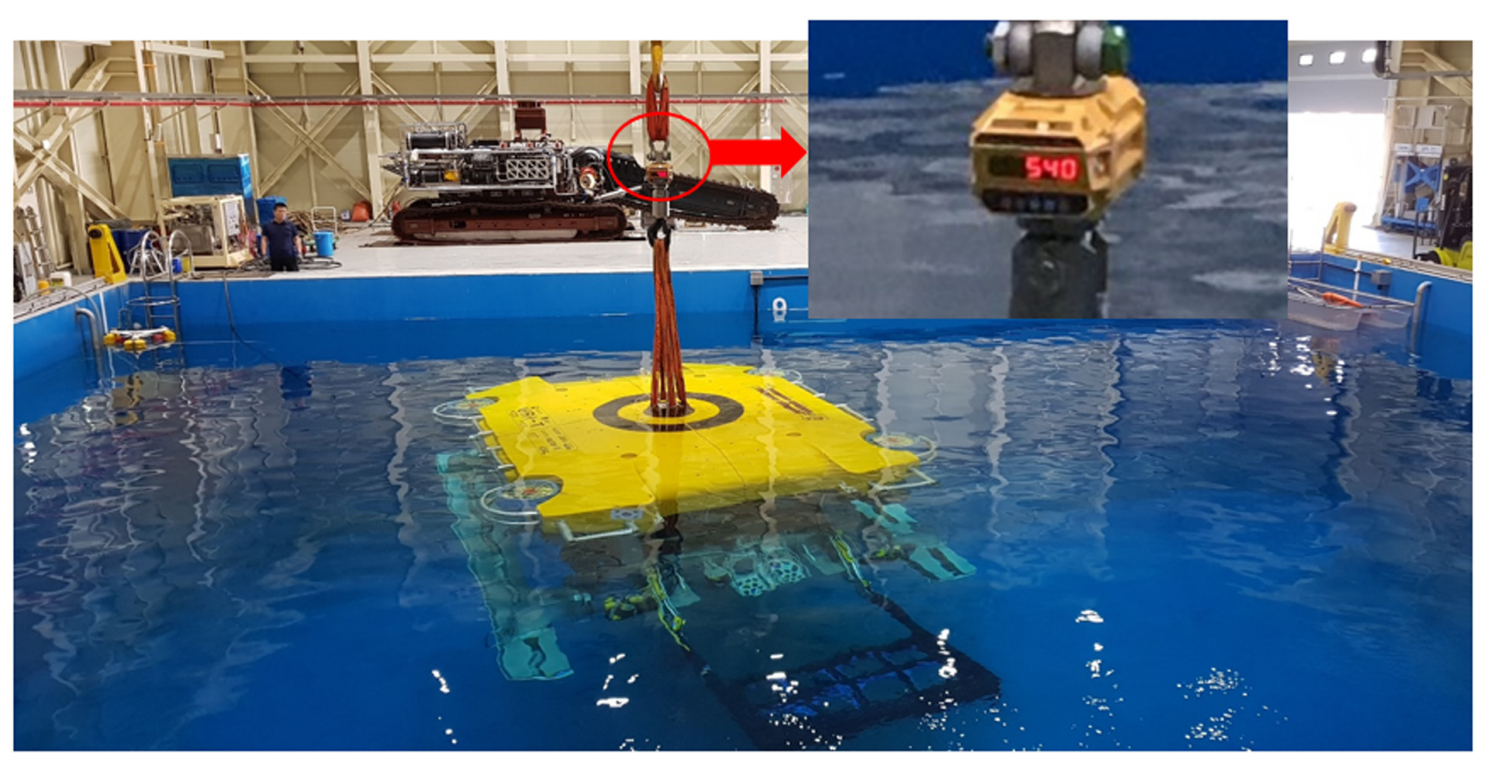

Fig. 22 URI-T's underwater weight in a state of repose $(540 \mathrm{~kg})$

다. 측정 결과 최대 속도 $1.7 \mathrm{~m} / \mathrm{s}$ 가 나왔고, 목표 성능 $1.54 \mathrm{~m} / \mathrm{s}$ 를 충족함을 확인했다.

요약하면, 1 차 실험과 유사한 장소에서 유사한 방법으로 실험 을 진행하였다. 앞서 미진했던 성과 목표인 전진 속도는 실험 조 건을 수정하여 진행하였고, $1.7 \mathrm{~m} / \mathrm{s}$ 의 결과를 얻었다. 더불어, 기 존의 성과 목표인 매설 깊이, 매설 속도를 각각 $3.01 \mathrm{~m}, 2.3 \mathrm{~km} / \mathrm{hr}$ 의 결과를 얻음으로써, 모든 목표 성능이 만족됨을 검증했다.

\section{4 수조에서 작업하중 실험}

마지막 성과 목표인 작업 하중 실험은 수조환경에서 진행되 었다. 실험방법은URI-T의 수중 무게를 $500 \mathrm{~kg}$ 이상으로 하고, 수 직 추진기 4대를 이용하여 상승운동을 한다. 이때 대용량 저울 에 보여지는 무게를 통해 작업 하중 목표를 검증한다. Fig. 22에 도시된바와 같이 URI-T가 수중에서 정지상태로 있을 때의 무게 는 $540 \mathrm{~kg}$ 이다. Fig. 23에서 수직 추진기를 구동시켰을 때 URI-T 의 무게는 $-20 \mathrm{~kg}$ 이다. 해당 실험으로, 수직 추력을 이용하여 $500 \mathrm{~kg}$ 이상의 작업 하중을 가짐을 검증하였다.

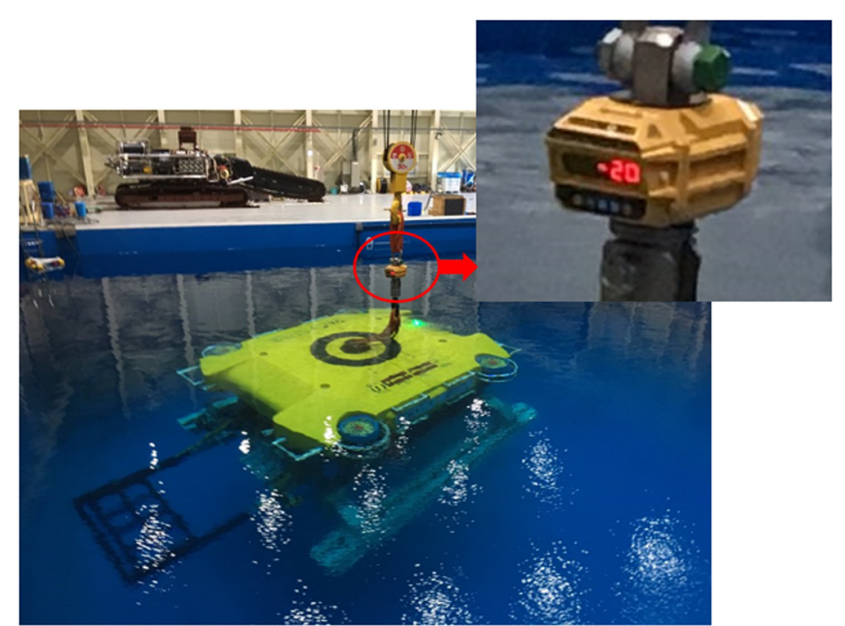

Fig. 23 URI-T's underwater weight in a state of driving $(-20 \mathrm{~kg})$

\section{4. 결언 및 향후계획}

본 논문에서는 개발된 케이블 및 소구경 파이프라인의 매설 및 유지보수 작업을 수행하는 $2,500 \mathrm{~m}$ 급 수중 중작업용 ROV 트 렌처인 URI-T를 소개하고, 실해역에서의 성능 검증 실험에 대 해 기술하였다. 두 번의 실해역 성능 검증 실험(2017.11, 2018. 08)과 한 번의 육상 성능 실험(2018.02)을 통하여 최대 매설 심 도, 매설 속도, 전진 속도가 목표 성능을 만족함을 확인하였다. 추후에 $500 \mathrm{~m}$ 수심의 실해역에서 최종 성능검증 실험(2018.10)이 계획되어있으며, 2019년 3월에 수중건설로봇사업단 1단계 사업 이 마무리되고, 2019년 4월부터 향후 4년간 시스템의 성능 향상 및 사용화를 목표로 2단계 사업이 계속될 전망이다.

\section{후 기}

본 논문은 해양수산부 재원으로 해양수산과학기술진흥원의 지원을 받아 수행된 연구임(해양개발용 수중건설로봇 사업단, PJT200539)

\section{References}

Ahn, S.H., Yu, J.S., Ryu, H.J., Hwang, S.B., Kim, C.W., Kim, D.S., 2011. Study on Submarine Cable Protection Methods for Grid Connection of Offshore Wind Farm. Proceedings of the Korean Society for Marine Environment \& Energy 2011, 205-211.

Christ, R.D., Wernli, R.L., 2014. The ROV Manual: A User Guide for Remotely Operated Vehicles. 2nd edition, Elsevier.

Jang, I.-S., 2014. Reporting: Korea Institute Ocean Science \& Technology Underwater Construction Robotics R\&D Center. Magazine of the Korean Society of Steel Construction, 26(2), 84-85. 
Jones, M., Hirai, M., 2001. A Novel ROV Developed for the Future Requirements of Cable Installation and Maintenance. Proceedings of SubOptic 2001, Kyoto, Japan, T6.3.4.

Kang, H.J., Lee, M.J., Kim, J.T., Kim, J.H., Jee, S.C., Hong, S.M, Kim, M.K., Li, J.H., 2016. Manufacture and Experiments of Experimental Ship-board Control System using EtherCAT Network for ROV Trencher. Proceedigns of ICROS 2016, 153-154.

Li, J.H., Kim, J.T., Lee, M.J., Jee, S.C., Kang, H.J., Kim, M.K., Kwak, H.W., Kim, S.B., Oh, T.W., 2015. Water Jetting Arm Optimal Design Consideration for a ROV Trencher. Proceedings of MTS/IEEE Oceans 2015, Genova, Italy. https://doi.org/ 10.1109/OCEANS-Genova.2015.7271388

Li, J.H., Kim, J.T., Lee, M.J., Lee, W.S., Kang, H.J., Han, S.C.,Lee, J.W., Kwak, H.W., 2014. Conceptual Design of Optimal Thrust
System for Efficient Cable Burying of ROV Threncher. Proceedings of MTS/IEEE Oceans 2014, Canada. https:// doi.org/10.1109/OCEANS.2014.7003153

Mole, P., Featherstone, I., Winter, S., 1997. Cable Protection: Solutions through New Installation and Burial Approaches. Proceedings of SubOptic 1997, San Francisco, CA, 34-39. Na, K.W, Jo, H.J, Baek, D.I, Hwan, J.H, Han, S.H, Jang, M.S, Kim, J.H, 2015. Study on Performance Evaluation of Subsea Waterjet Trenching Machine Using Water Tank. Journal of Ocean Engineering and Technology, 29(6) 470-474. https:// doi.org/10.5574/KSOE.2015.29.6.470

Yoo, J.D., Shin, H.S., 2010. Analyses of the Submarine Cable Faults of EAC and Protection Ways. The Journal of the Korea Institute of Electronic Communication Sciences, 5(3), 227-232. 